\title{
The Black Lad of Ashton-under-Lyne
}

\section{Kate Griffith}

To cite this article: Kate Griffith (1898) The Black Lad of Ashton-under-Lyne, Folklore, 9:4, 379-382, DOI: 10.1080/0015587X.1898.9720476

To link to this article: http://dx.doi.org/10.1080/0015587X.1898.9720476

$$
\text { 曲 Published online: } 14 \text { Feb } 2012 .
$$

Submit your article to this journal $\pi$

Q View related articles $₫$ 
stories of ghosts, witches, fairies, \&c, exactly as they exist in popular tradition. We have many essays and articles on "Highland Superstition, " but most of them have the fault of being too general, or of giving their illustrations in a form that is hardly original. The tales ought always to be taken down in the exact words of the speaker, especially as many Highlanders are excellent narrators of such stories. Not only would such collections be of great service to Celtic students, by giving genuine specimens of various dialects, but they would in time form a body of Highland folklore which might stand farourably in comparison with that of other countries, with Jon Ánason's two volumes of Icelandic tales, for instance, or E. T. Kristensen's many publications in Danish. Gaelic folklore cannot but suffer if it is only given in English forms, and half-a-dozen willing workers would not be long in covering the greater part of the ground. It is well, too, that the work should be done very soon, before printed sources have vitiated local tradition, as they have done in several districts already.

W. A. Crajarr

\section{Thr Black Lad of Ashton-Under-Lyne}

[Dr. Trior has been good enough to forward the following letter addressed to him by Mrs. F. H. Griffith, of Riversvale, Ashtonunder-Lyne, together with the notes appended.]

Drar Dr. TyLor,

Herewith are what I promised you: all the facts relating to the immemorial custom of "Riding the Black Lad" in Ashton: under-Lyne on the afternoon of Easter Monday, which I was able to gather in 1895 from old people, upwards of eighty years of age, who could tell me something of the practices prevailing before the outrageous proceedings connected with this rite were suppressed about 1830 or 1832 . Each assured me that everybody connected with the rites was "very low," that the whole thing had been "a 'disgrace to the place," and some added that "the sooner such things were forgotten the better." . So my informants, being all "decent folk," had never been allowed by their parents and guardians to take part in the performances. -

All the answers which I could get to all my questions I hive in writing; in the notes I send you the data are sifted and chassificd. At the present day several Black Lads are ridden round the 
town on the afternoon of Easter Monday, escorted by noisy men who rattle money boxes and invite passers-by to contribute to the "Blake Lad," i.e. to give them money for drink. The effigies generally have black-gloved hands, and hold the reins ; but still the black suit is in favour. There is always one Black Lad with some claim to legitimacy, for whom the annual ten shillings is duly paid from the estate office.

I might also mention that in Ashton and district the custom of "lifting"-especially women-was another Easter terror to all "decent folk" abroad on that day.

If you can lay your hands on Butterworth's History of Ashtonunder-Lyne you will be interested by the allusions to old local customs contained in "The Custom Roll and Rental of the Manor of Assheton-under-Lyne." This first recites "The Covenant made between John of Assheton, Knight, and tenants of the town of Assheton, of their swine, the year of the reign of King Richard the Second after the Conquest, the third, that the aforesaid tenants shall have their swine going in the demesnes of the aforesaid town etc." Then follows an agreement about corn-grinding, Ist year Henry IV., and finally the Rent Roll of John de Assheton-anno Regni Regis Henrici Sexti primo: "At the feast of Martin in winter etc. All the tenants of the Lordship of Assheton-under-Lyne, taking their tenements to farm for twenty winter term, at John of Assheton, Knight, the which came out of Normandy. At the same Feast, with all the services, customs, and usages, as after is in this book written and rehearsed, and as it has been used and customed of old time, \&c., \&c."

Happily some sort of copy or translation was made of this document last century, for now the trustees of the estate will not allow any of the muniments to be examined by any one. With regard to the Black Iad, for instance, one thing wanted is to trace the payments for the rite in the old Manor Court Rolls as far back as may be. This is not permitted.

Before reading the notes will you see in Hone's Every Day Book, vol. ii., March 27, "Riding the Black Lad. An account of an ancient usage still maintained under this name at Ashtonunder-Lyne will be found in the annexed letter "? The letter is dated Ashton-under-Lyne, March, 1826.

Yours sincerely,

Katr Gritrith. 


\section{The Effigy.}

All agree that the body was made of sacking stuffed with hay or straw, among which gunpowder was sometimes put. It was clothed in a black suit-generally velvet.

On the back were put the initials of the last couple married in the parish church in the Old Year. (As the year drew to a close there was great competition to avoid this distinction.)

The "arms" were sticks stretched out at right angles to the sides, and the "hands" were bunches of daffodils, or holly, or "besoms."-i.e. ling.

The head was wooden, and on it was placed a helmet. Some say its face was florid, some bronzed, some black. (The head was kept from year to year; see below.)

The figure was always carried round on horseback.

\section{The Ceremonies.}

The Black Lad was always taken first to the Hall, and afterwards through all the oldest-which were generally also the roughest-parts of the town, his noisy escort everywhere asking for money and drink. At the end of his rounds his head was detached and thrown to be scrambled for; the man who secured it receiving money in exchange for the head where it was kept for use at the following Easter. It used to be kept at the Hall, afterwards it was simply exhibited there, or at the estate office, and lodged at some public-house until next wanted. Some say that the body was stripped of its velvet suit, which was divided among old women to make bonnets for themselves.

The body was then taken (some say dragged by the legs) to the Old Cross; there it was hung up and shot at intil set on fire (some say it was also shot at while being carried through the town, but this seems to have been a comparatively modern innovation, in no way part of the old rites). It was then torn to pieces, and the fragments flung amiong the crowd. At this point, or thereabouts, the water in the marl-pit (then known as "Garther's Reservoir ") was let out by, the cutting of a sluice, and ran down the narrow street now known as Cricket's Lane or Cricketty -a dirty stream flowing the whole width of the way-into the place of the Old Cross. Here, not only the burning fragments of the Black Lad, but any rags, sickings, or mops which could be obtained were dipped in the slutch and used for clouting and 
bemiring more especially women, but also any strangers or respectable-looking people. The surrounding shops, and indeed most of the shops in the town, were closed for the afternoon and evening, and all decent folk, rich or poor, kept out of the way.

\section{Popular Tradition as to Origin of the Black Lad.}

Throughout this century, at any rate, it has been universally believed that the Black Lad represents "the wicked Knight of Assheton," Sir Ralph de Assheton. He has, however, never yet been successfully identified. The tradition has been that he was a great oppressor of the tenantry -in this all agree. Some give details : he kept his prisoners in dungeons beneath the two old round towers (pulled down only a few years ago), with serpents and toads; he used to put people-sometimes women-in barrels spiked inside, and roll them from the top of the steep hill on which the Hall stood overlooking the river, down the ascent to it known 2s Ann's Brow. "Ann's Brow"-i.e. the path or ascent to the Hall-lay between the Hall and "Spring Pasture," which was on the east (B) slope of the hill. Some say that he was chiefly hated because of his stern dealings with farmers who allowed a certain yellow weed to grow on their land.

The main idea that the Black Lad represented someone to be well hated led to his being made in the likeness of the Czar in the Crimean year; that, however, was an exception and a very late one.

\section{Connection with the Estate.}

The steward of the estate, who has been in the office between 60 and 70 years, says that during the whole of that time to his knowledge ten shillings have always been given on the afternoon of Easter Monday to the men who bring the head in proof that the rites have been properly celebrated.

Some say that the head used to be always kept at the Hall.

The older people remember the tradition being current that a field was set apart for the keep of the borse that carried the Black Lad. Some of them say it was "Gallow's Field;" down near the River Tame, others that it was "Spring Pasture." Both fields were close to the Hall.

The Black Lad was always taken first to the Hall.

The water let out was from the marl-pit belonging to the estate. 